\title{
A STUDY ON TRADITIONAL MARKET MANAGEMENT TOWARDS BLIMBING MARKET IN MALANG CITY
}

\author{
Rachmad Yusuf Susanto \\ Faculty of Economics, University of Tribhuwana Tunggadewi Malang \\ rachmadyusufsusanto@yahoo.co.id
}

\begin{abstract}
As related to the rate of business scale fast growth and the very tight competition in the business world, the needs of society also increase by degrees from time to time. The existence of traditional market in Indonesia is dealing with tight competition from modern market, on which the rate of modern market growth is out of control. The position of traditional market has been eliminated by slowly due to the conducive situation within modern market by which the price of goods including service offered to consumers is very competitive. That's the fact that most of consumer prefer to go shopping to modern market instead of traditional market. Traditional market throughout Indonesia continue to make an effort to survive against the more and more aggression carried out by modern market in offering all of the goods to be selled. The government has full responsibility to protect the existence of traditional market which is a backbone of government economy especially in establishing the full employment and contributing to local government income. The analysis in this research is traditional market merchant who has established their business in Pasar Blimbing Kota Malang. This research involved the 50 respondents which were sampled by simple random sampling method, among others: direct observation, interview, scrutinize documentation, distributing questionnaires to collect primary data. While secondary data was collected indirectly from the other parties. The aim of this research is to find out more how far the active role of the government in protecting the existence of traditional market against the more and more aggression carried out by modern market in offering all of the goods to be selled.
\end{abstract}

Keywords: Traditional Market, Management, The Role Of The Government

\section{STUDI TENTANG PENGELOLAAN PASAR TRADISIONAL PADA PASAR BLIMBING KOTA MALANG}

\author{
Rachmad Yusuf Susanto \\ Fakultas Ekonomi, Universitas Tribhuwana Tunggadewi Malang \\ rachmadyusufsusanto@yahoo.co.id
}

\begin{abstract}
ABSTRAK
Berkait dengan perkembangan pesatnya skala usaha dan semakin kerasnya pola persaingan di dunia usaha, maka pola kebutuhan masyarakat juga semakin
\end{abstract}


berkembang. Keberadaan pasar tradisional di wilayah Indonesia sedang menghadapi persaingan berat dari pasar modern, dimana menjamurnya pertumbuhan pasar modern sudah diluar kendali. Posisi pasar tradisional semakin terkikis dikarenakan suasana yang terjadi di pasar modern sangat kondusif dimana harga-harga barang yang ditawarkan berikut pelayan yang diberikan oleh pasar modern sangat kompetitif. Hal ini mengakibatkan banyaknya konsumen yang beralih belanja ke pasar modern. Pasar tradisional di seluruh wilayah Indonesia berusaha keras untuk bertahan terhadap serangan dari pasar-pasar modern yang kian lama kian marak. Pemerintah bertanggung jawab penuh melindungi keberadaan pasar tradisional yang merupakan ujung tombak perekonomian pemerintah khususnya dalam membuka lapangan kerja dan memberikan kontribusi pendapatan pemerintah daerah. Analisis dalam penelitian ini adalah pedagang pasar tradisional yang membuka usahanya di Pasar Blimbing Kota Malang. Teknik pengambilan sampel yang digunakan dalam penelitian ini dilakukan secara random sampling terhadap 50 pedagang pasar tradisional Pasar Blimbing Kotamadya Malang dengan cara, antara lain : menggunakan teknik observasi langsung, teknik wawancara, melihat dokumentasi dan penyebaran kuesioner untuk mendapatkan data primer. Data sekunder didapatkan dengan cara mengumpulkannya secara tidak langsung dari pihak lain. Tujuan dari penelitian ini adalah untuk mengetahui sampai sejauh mana peran aktif pemerintah dalam melindungi keberadaan pasar tradisional terhadap serangan pasar modern.

Kata Kunci: Pasar Tradisional, Pengelolaan, Peran Pemerintah.

\section{PENDAHULUAN}

Perekonomian di sebuah kota akan mengalami perkembangan pesat seiring dengan meningkatnya kegiatan perdagangan di kota tersebut dan kota di sekitarnya. Salah satu sarananya yang ada di kota adalah pasar, baik pasar tradisional maupun pasar modern. Perdagangan merupakan konsep perekonomian dan titik fokus terpenting dalam rangka memperbaiki dan meningkatkan kesejahteraan masyarakat serta menjadi sentral perekonomian di dunia. Dalam perdagangan dilakukan penawaran berbagai macam produk untuk membantu memenuhi kebutuhan hidup sehari-hari, baik untuk diproduksi lebih lanjut maupun untuk memenuhi kebutuhan-kebutuhan konsumen. Salah satu tempat kegiatan dalam penyelenggaraan usaha perdagangan adalah di pasar. Pasar disini menjadi salah satu sarana ekonomi yang menjadikan tolok ukur dalam peningkatan pendapatan ekonomi suatu daerah. Seiring dengan perkembangan zaman, pasar tidak hanya menjadi tempat transaksi antara penjual dan pembeli saja melainkan pasar telah menjadikan suatu sarana penggerak roda perekonomian masyarakat dalam skala besar. Disamping itu pasar tidak bisa dilepaskan dari kehidupan seharihari masyarakat Indonesia, yang mayoritas penduduknya berasal dari golongan menengah kebawah. Berbagai kebutuhan hidup seperti 
kebutuhan sandang, pangan, papan, dan sebagainya dapat diperoleh di pasar (Nurhayati, 2013).

Pasar adalah orang orang yang mempunyai keinginan untuk puas, uang untuk belanja, dan kemauan untuk membelanjakannya.(Basu

Swasta, 1995).

Menurut Prianto (2008:10), pasar dijelaskan sebagai kumpulan para penjual dan pembeli yang saling berinteraksi, saling tarik-menarik kemudian menciptakan harga barang di pasar. Seiring dengan perkembangan zaman dan semakin pesatnya perkembangan teknologi dewasa ini, maka pasar tidak hanya sebagai tempat terjadinya transaksi jual-beli bagi masyarakat yang ada di sekitar pasar, lebih dari itu pasar telah dijadikan sebagai sarana penggerak roda perekonomian dalam skala besar (Nidya dalam Mirah, 2013).

Menurut pandangan Stanton (dalam Sudirmansyah, 2011), pasar adalah orang-orang yang mempunyai keinginan untuk memenuhi kebutuhan. Menurut bentuk fisik, pusat perdagangan dibagi menjadi dua yaitu pasar tradisional dan pusat perbelanjaan modern (Ayuningsasi, 2010).

Menurut Peraturan Presiden RI No. 112 Tahun 2007, pasar tradisional adalah pasar yang dibangun dan dikelola oleh Pemerintah, Pemerintah Daerah, Swasta, Badan Usaha Milik Negara, dan Badan Usaha Milik Daerah termasuk kerja sama dengan swasta dengan tempat usaha berupa toko, kios, los, dan tenda yang dimiliki atau disewa oleh pedagang kecil, menengah, swadaya masyarakat atau koperasi dengan usaha skala kecil, modal kecil, dengan proses jual beli barang dagangan melalui tawar menawar. Dalam Perpres tersebut juga disebutkan bahwa toko modern adalah toko dengan sistem pelayanan mandiri, menjual berbagai jenis barang secara eceran dengan bentuk minimarket, supermarket, atau department store. Sedangkan Peraturan Presiden (Perpres) No 112 Tahun 2007 tentang penataan dan pembinaan pasar tradisional, pusat perbelanjaan, serta toko modern (biasa disebut perpres pasar modern), dan dalam Peraturan Daerah No 2 Tahun 2002 tentang perpasaran swasta, sudah diatur bahwa jarak antara pasar tradisional dan modern minimal 2,5 kilometer.

Dalam lingkup pasar tradisional sebagai pasar pemerintah, terdapat 3 pelaku utama yang terlibat dalam aktivitas sehari hari, yaitu : Penjual, Pembeli dan Pegawai/Pejabat Dinas pasar (Riasto Widiatmono,Jurnal Bisnis Srategi, 2006).

Pasar tradisional telah memainkan fungsi dan peranan penting sebagai sumber utama mata pencaharian dan pengembangan ruang pedesaan (Angmor, 2012). Pasar tradisional merupakan tempat kerja yang memiliki banyak nilai strategis bagi pedagang kecil (Febrianty, 2013). Pedagang pasar tradisional memerlukan tempat untuk menjajakan bermacam-macam barang dagangannya. Mereka selalu mencari tempat yang ramai dikunjungi pembeli. Sayangnya, belum ada solusi yang memadai untuk mereka. Seolah-olah ada kecenderungan dibiarkan saja, sehingga mereka menempati pinggiran 
jalan untuk menjual barang dagangannya. Pada kenyataannya para pedagang kecil dan pasar tradisional semakin terimpit dengan berkembang pesatnya pasar modern seperti Minimarket, Alfamart, Indomaret, Mall, Supermarket, Hypermarket, Department Store dan lain lain. Padahal, pasar tradisional merupakan asset utama daerah yang telah menghidupi banyak orang. Jutaan orang telah menggantungkan kehidupannya pada pasar tradisional dimana pasar tradisional ini berperan sebagai salah satu kontributor (penyumbang) pendapatan asli daerah terutama di sektor perpajakan.

\section{KERANGKA TEORI}

Pengelolaan merupakan terjemahan dari Management. Istilah manajemen berasal dari kata to manage yang berarti mengatur dan mengurus. Manajemen sendiri merupakan suatu proses untuk mencapai sebuah tujuan yang ingin dicapai melalui bantuan orang lain. Stoner dalam Handoko menyatakan bahwa manajemen (pengelolaan) adalah proses perencanaan, pengorganisasian, pengarahan dan pengawasan usahausaha para anggota organisasi dan penggunaan sumberdaya organisasi lainnya agar mencapai tujuan organisasi yang telah ditetapkan. Pasar tradisional merupakan tempat bertemunya penjual dan pembeli serta ditandai dengan adanya transaksi penjual pembeli secara langsung dan biasanya ada proses tawar-menawar, bangunan biasanya terdiri dari kioskios atau gerai, los dan dasaran terbuka yang dibuka oleh penjual maupun suatu pengelola pasar.

Pada umumnya pedagang pasar tradisional menjual barang-barang untuk kebutuhan sehari-hari baik kebutuhan pokok seperti beras, gula, garam, mie, minyak goreng, telur, rempah-rempah maupun kebutuhan sekunder seperti bahan-bahan makanan berupa ikan, daging, buah, sayursayuran, kain, pakaian, alat tulis, alat masak, barang elektronik, jasa dan lainlain. Selain itu, ada pula yang menjual kue-kue dan barang-barang lainnya.

Yang dimaksud dengan pengelolaan pasar tradisional adalah merupakan keseluruhan aktivitas penataan yang meliputi perencanaan, pelaksanaan dan pengendalian pasar tradisional.

Ruang lingkup pengelolaan pasar tradisional di lingkungan Pasar Blimbing Kota Malang terdiri dari:

a. Ketertiban dan keamanan pasar

b. Kebersihan dan kenyamanan

c. Persampahan

d. Parkir

e. Penyediaan serta pemeliharaan sarana dan prasarana pasar

f. Perizinan serta penataan pedagang dan PKL

g. Penetapan dan pemungutan retribusi

h. Laporan dan pertanggungjawaban

i. Sanksi

Adapun tujuan dari pengelolaan pasar tradisional adalah sebagai berikut:

i. Memberi kepastian hukum bagi penyelenggara pasar tradisional

ii. Mewujudkan ketertiban, keamanan, kebersihan dan kenyamanan pasar tradisional 
iii. Mengatur dan menata keberadaan dan pendirian pasar tradisional

iv. Memberikan pembinaan dan perlindungan usaha kepada pasar tradisional

v. Terselenggaranya kemitraan antara pelaku usaha pasar tradisional

Ciri manajemen yang baik adalah apabila setiap fungsi/jabatan di dalam struktur organisasi memiliki tugas dan tanggung jawab yang benar dan jelas, kinerja yang dicapai dapat diukur sesuai dengan yang tertuang di dalam SOP (Standard Operation Procedure).

\section{INDIKATOR PENGELOLAAN PASAR YANG BERHASIL}

(Sambutan Menteri Perdagangan Republik Indonesia, Mari Elka Pangestu)

1) Manajemen Yang Transparan Pengelolaan manajemen pasar yang transparan dan profesional. Konsekuen dengan peraturan yang ditegakkannya dan tegas dalam menegakkan sanksi jika terjadi pelanggaran.

2) Keamanan

Satuan pengamanan pasar bekerja dengan penuh tanggung jawab dan bisa melakukan koordinasi dan kerjasama dengan para penyewa/pedagang. Para penghuni memiliki kesadaran yang tinggi untuk terlibat dalam menjaga keamanan bersama.

3) Sampah

Sampah tidak bertebaran di manamana. Para pedagang membuang sampah pada tempatnya. Tong sampah tersedia di banyak tempat, sehingga memudahkan bagi pengunjung untuk membung sampahnya. Pembuangan sampah sementara selalu tidak menumpuk dan tidak membusuk karena selalu diangkut oleh armada pengangkutan sampah ke tempat pembuangan akhir secara berkala.

4) Ketertiban

Tercipta ketertiban di dalam pasar. Ini terjadi karena para pedagang telah mematuhi semua aturan main yang ada dan dapat menegakkan disiplin serta bertanggung jawab atas kenyamanan para pengunjung atau pembeli.

5) Pemeliharaan

Pemeliharaan bangunan pasar dapat dilakukan baik oleh pedagang maupun pengelola. Dalam hal ini telah timbul kesadaran yang tinggi dari pedagang untuk membantu manajemen pasar memelihara sarana dan prasarana pasar seperti saluran air, ventilasi udara, lantai pasar, kondisi kios dan lain sebagainya.

6) Pasar Sebagai Sarana/Fungsi Interaksi Sosial

Pasar yang merupakan tempat berkumpulnya orang-orang dari berbagai suku di tanah air menjadi sarana yang penting untuk berinteraksi dan berekreasi. Tercipta suasana damai dan harmonis di dalam pasar.

7) Pemeliharaan Pelanggan

Para penjual memiliki kesadaran tinggi akan pentingnya menjaga agar para pelanggan merasa betah berbelanja dan merasa terpanggil untuk selalu berbelanja di pasar. 
Tidak terjadi penipuan dalam hal penggunaan timbangan serta alat ukur lainnya. Harga kompetitif sesuai dengan kualitas dan jenis barang yang dijual, serta selalu tersedia sesuai kebutuhan para pelanggan.

8) Produktifitas Pasar Cukup Tinggi Pemanfaatan pasar untuk berbagai kegiatan transaksi menjadi optimal. Terjadi pembagian waktu yang cukup rapi dan tertib:

a. Pukul 05.30 s/d 09.00 aktifitas pasar diperuntukkan bagi para pedagang kaki lima khusus makanan sarapan/jajanan pasar.

b. Pukul 04.00 s/d 17.00 aktifitas pasar diperuntukkan bagi para pedagang kios \& lapak dan penjualan makanan khas.

c. Pukul $06.00 \mathrm{~s} / \mathrm{d} \quad 24.00$ aktifitas pasar diperuntukkan bagi para pedagang Ruko.

d. Pukul 16.00 s/d 01.00 aktifitas pasar diperuntukkan bagi para pedagang Cafe Tenda.

9) Penyelenggaraan Kegiatan (Event) Sering diselenggarakan kegiatan peluncuran produk-produk baru dangan membagikan berbagai hadiah menarik kepada pengunjung. Ini dilakukan bekerja sama dengan pihak produsen.

10) Promosi dan "Hari Pelanggan" Daya tarik pasar tercipta dengan adanya karakteristik dan keunikan bagi pelanggan. Daya tarik ini harus dikemas dalam berbagai hal, mulai dari jenis barang dan makanan yang dijual hingga pada berbagai program promosi. Manajemen pasar bekerjasama dengan para pedagangnya menentukan hari-hari tertentu sebagai "Hari Pelanggan", dimana dalam satu waktu tertentu para pedagang melakukan kegiatan yang unik seperti berpakaian seragam daerah atau menyelenggarakan peragaan pakaian atau makanan daerah tertentu dan lain sebagainya.

\section{METODE PENELITIAN}

Penelitian studi tentang Pengelolaan Pasar Tradisional pada Pasar Blimbing Kota Malang ini menggunakan metode analisis deskriptif kualitatif yaitu menganalisis dan mendeskripsikan atau menggambarkan berbagai kondisi dan situasi berbagai data yang dikumpulkan berupa hasil wawancara mengenai masalah yang diteliti. Pendekatan kualitatif menjadikan suatu pendekatan yang dominan di dalam penelitian ini. Populasi dalam penelitian ini adalah pedagang pasar tradisional yang membuka usahanya di Pasar Blimbing. Sedangkan target sampel dalam penelitian ini adalah para pedagang pasar tradisional yang membuka usahanya di Pasar Blimbing. Dalam penelitian ini, pengambilan sampel yang dilakukan adalah sebanyak 50 pedagang pasar tradisional

Teknik pengambilan sampel yang digunakan dalam penelitian ini dilakukan secara random dengan cara, antara lain : menggunakan observasi langsung, wawancara, melihat dokumentasi dan penyebaran kuesioner 
untuk mendapatkan data primer. Data sekunder didapatkan dengan cara mengumpulkannya secara tidak langsung dari pihak lain. Analisis terhadap pengelolaan pasar tradisional ini adalah sebagai bahan acuan terhadap langkah-langkah apa yang harus diambil dan dipertahankan pengelola pasar tradisional agar dapat bertahan dalam menghadapi persaingan dengan menjamurnya pertumbuhan pasar modern yang semakin lama tidak terkendali. Dan sekaligus secara lambat laun akan menyingkirkan keberadaan pedagang di pasar tradisional secara umum dan pedagang tradisional Pasar Blimbing secara khusus. Bila hal ini tidak tertangani sedini mungkin tentunya akan berpengaruh terhadap pendapatan pajak Pemerintah Kota Malang.

\section{HASIL PENELITIAN DAN PEMBAHASAN}

Hampir semua barang dagangan yang dijual di pasar tradisional adalah hasilhasil panen petani kecil yang berada diwilayah pedesaan. Masyarakat kota sangat tergantung dengan petani yang menjual hasil olahan tanahnya untuk dibawa ke kota.

Pasar tradisional sebagai pusat transaksi perbelanjaan ditengah menjamurnya pertumbuhan pasar modern seperti Minimarket, Alfamart, Indomaret, Mall, Supermarket, Hypermarket, Department Store di wilayah Kota Malang telah berperan aktif dalam menunjang Program Pemerintah untuk meningkatkan pendapatan asli daerah (PAD), sekaligus menjadikan tulang punggung pembangunan ekonomi daerah dengan menyerap tenaga kerja. Sehingga dapat menunjang peningkatan perekonomian masyarakat secara mikro dan peningkatan perekonomian bangsa secara makro.

Pasar tradisional juga berfungsi sebagai forum silaturahmi antara pembeli dan penjual, saling kenal dan mengenal, sehingga budaya hidup kekeluargaan yang tinggi, yang telah dibangun oleh nenek moyang bangsa Indonesia sangat terjaga di pasar tradisional ini.

Dari ke 50 pedagang pasar tradisional ini terdiri dari 25 orang tidak terdidik, 10 orang tidak lulus sekolah dasar, 10 orang lulusan sekolah dasar dan 5 orang lulusan SLTP. Pedagang tersebut berjualan dalam kurun waktu yang lama. Ada yang menetap di pasar, ada yang datang berdagang mulai jam dua pagi sampai siang hari dan sore hari. Bahkan ada beberapa pedagang pasar tradisional yang berdagang hingga malam hari. Dampak yang terjadi dari pengelolaan Pasar Blimbing di sini adalah persaingan di antara pedagang sehingga sering menimbulkan konflik di antara mereka dengan menempuh berbagai cara yang tidak beretika seperti saling menjelekkan mutu barang dagangannya satu sama lain. Sehingga terjadi hubungan yang tidak harmonis dan selanjutnya membuat hubungan para pedagang tradisional menjadi renggang satu sama lain. Total skor persaingan di sini telah mencapai $55 \%$ dengan kesimpulan bahwa persaingan di antara pedagang tradisional semakin meningkat. Namun demikian, jumlah pedagang yang mengeluh karena merasakan bahwa 
menurunnya jumlah pembeli telah berakibat meningkatnya persaingan antar pedagang yang semakin lama semakin ketat. Persaingan ketat antar pedagang berakibat pada munculnya pertikaian atau konflik antara pedagang yang satu dengan pedagang yang lain di Pasar Blimbing, dimana antar sesama pedagang sering terjadi persaingan yang tidak sehat.

Berdasarkan hasil penelitian yang dilakukan oleh peneliti dapat diketahui bahwa faktor yang paling dominan dan menjadikan suatu penyebabnya adalah berkurangnya jumlah pembeli yang berbelanja ke Pasar Blimbing dimana hasil perhitungan total skor mengenai menurunnya penghasilan pedagang akibat sepi pengunjung adalah sebesar sebesar $70,7 \%$. Kesimpulan dalam persentase tersebut telah menunjukkan pedagang tradisional di Pasar Blimbing telah mengalami penurunan omzet penjualan sebagai akibat dari berkurangnya sejumlah pembeli yang berkunjung ke Pasar Blimbing.

Menurunnya jumlah pembeli tersebut disebabkan karena kondisi lingkungan pasar yang semrawut, kumuh dan becek (apalagi di waktu musim penghujan) serta semakin menjamurnya pertumbuhan pasarpasar modern di lingkungan Pasar Blimbing yang tidak terkendali. Disamping itu keadaan pasar modern yang lebih aman, bebas parkir serta penerangan cahaya dan ventilasi udara yang memadai telah membuat pengunjung pasar modern semakin bertambah. Di samping itu pembeli dipastikan betah dan dapat berlama lama di dalam pasar. Karena lingkungan pasar yang kondusif.

\section{KESIMPULAN}

Pengelolaan pasar belum dilaksanakan secara optimal dikarenakan sarana pasar yang kurang mendukung, kondisi lingkungan pasar yang semrawut, kumuh dan becek (apalagi di waktu musim penghujan) serta semakin menjamurnya pertumbuhan pasar-pasar modern di lingkungan Pasar Blimbing yang tidak terkendali. Penurunan jumlah pedagang dan meningkatmya persaingan antar pedagang akan memberikan dampak sosial sebagai akibat dari menjamurnya pertumbuhan pasar-pasar modern yang tidak terkendali. Hal ini dapat dipastikan merupakan suatu ancaman yang serius bagi keberadaan pasar tradisional. Lambat laun pasar tradisional yang dibutuhkan oleh masyarakat golongan menengah kebawah akan mati dan kalah bersaing dengan pasar modern sehingga kesejahteraan masyarakat tidak akan tercapai.

Lemahnya manajemen pasar tradisional disebabkan oleh pengelola pasar belum dapat menjalankan fungsinya secara optimal dan tidak didukung dengan standard operation procedure (SOP) yang jelas. Begitu pula para pedagang pasar tradisional dalam memperoleh pengalaman berdagang hanya ditempuh secara otodidak, tetapi belum diberikan pembinaan dari segi manajemen dan pengaturan permodalan. Sesungguhnya kondisi nyata yang terjadi di pasar tradisional adalah bahwa pasar tersebut secara alami telah memiliki 
keunggulan bersaing yang tidak dimiliki oleh pasar modern manapun.

Adapun keunggulan bersaing tersebut dapat dibuktikan dengan letak lokasi pasar yang strategis, wilayah maupun daerah penjualan yang luas, barang-barang yang dijual selain lengkap juga beraneka ragam, harga jual yang terjangkau dan sistem tawar menawar barang yang dijual telah menunjukkan suasana keakraban dan kekeluargaan di antara para penjual dan pembeli.

Segala bentuk transaksi barang yang terjadi di lingkungan pasar tradisional tidak mengacu pada maksimum laba atau minimum kerugian, tetapi terdapat suatu kebutuhan sosial yang sangat diperlukan atau dituntut pihak lain dalam bentuk kebutuhan penghargaan yang bersifat timbal-balik dalam hubungan kekeluargaan secara setara, yaitu dengan terjalinnya ikatan hubungan emosional yang bersifat pribadi.

\section{SARAN}

Adapun dalam pengelolaan pasar tradisional ini pihak pemerintah harus menitik beratkan kepada hal-hal, yang antara lain adalah sebagai berikut:

a. Pemerintah harus berfokus pada penciptaan, perluasan dan pemerataan kesempatan kerja. Mengingat tenaga tidak terdidik yang pada umumnya bermukim di sekitar pasar tradisional sulit mencari pekerjaan. Dengan menurunnya angka pengangguran dapat mengurangi tingkat kejahatan.

b. Pemerintah harus menyusun rencana kerja yang sekaligus mencanangkan program peningkatan pendapatan dan kesejahteraan masyarakat daerah, mengingat keberadaan pasar tradisional telah berperan aktif sebagai penyumbang utama (kontributor) di sektor pendapatan asli daerah (PAD).

c. Pemerintah harus dapat memanfaatkan sumberdaya manusia di sekitar pasar tradisional sehingga dapat berperan aktif dalam kemajuan daerah.

d. Pemerintah harus mempertahankan, menjaga dan melestarikan keberadaan pasar tradisional agar tidak terkikis dengan menjamurnya pertumbuhan pasar-pasar modern yang semakin tidak terkendali.

e. Pemerintah harus dapat melakukan promosi guna meningkatkan daya saing pasar tradisional terhadap pasar-pasar modern dengan cara melakukan koordinasi antar lembaga terkait seperti lembaga pemerintah, masyarakat, pelaku pasar, warga pasar, instansi terkait maupun stakeholder lainnya.

f. pengamatan peneliti bahwa pasar tradisional masih berpotensi sekali untuk bertahan dalam menghadapi serangan maupun ancaman dari pertumbuhan pasar modern yang sudah di luar kendali dan kian marak. Oleh sebab itu, Pemerintah Kota Malang disarankan menyusun konsep baru tentang pasar tradisional dengan cara memberikan pembinaan secara fundamental tentang teknik penjualan kepada pedagang pasar tradisional yang mengarah kepada 3P (Product, Price dan Place). Untuk product perlu 
ditanamkan prinsip kejujuran terhadap kualitas barang yang ditawarkan. Untuk price agar ditanamkan prinsip kompetitif dalam menghadapi pesaing. Untuk place agar ditanamkan prinsip kebersihan dan keindahan untuk mendorong konsumen berminat mengunjungi dan berbelanja di pasar tradisional.

\section{DAFTAR PUSTAKA}

Ayuningsasi, Anak Agung Ketut. 2010. Analisis Pendapatan Pedagang Sebelum dan Sesudah Program Revitalisasi Pasar Tradisional di Kota Denpasar (Studi Kasus Pasar Sudha Merta Desa Sidakarya). Jurnal Piramida, 7 (1)

Basu Swasta (1995), Pengantar Bisnis Modern, Penerbit Liberty, Yogyakarta.

Handoko, T. Hani. (2011). Manajemen. Yogyakarta: BPFE Yogyakarta.
Mirah Pradnya Paramita, Anak Agung. 2013. Efektivitas dan Dampak Program Revitalisasi Pasar Tradisional di Pasar Agung Peninjoan. Jurnal Piramida, 2 (5). Avaliabel at : ejournal.unud.ac.id Nurhayati, Lalis. 2013. Hasil Observasi Tentang Sikap Pembeli terhadap Pedagang di Pasar Gede Bage. Diakses dari http://lalisnurhayatiii.blogspot.co $\mathrm{m} / 2013 / 05 /$ hasil-observasitentang-sikap-pembeli.html. Diunduh tanggal 27 November 2014.

Prianto, Agus. 2008. Ekonomi Mikro. Malang: SETARA Press.

Sudirmansyah. 2011. Pengertian dan Jenis-jenis Pasar. Diakses dari http://www.sudirmansyah.com/a rtikel-ekonomi/pengertian-danjenis-jenis pasar.html. Diunduh tanggal 30 Maret 2013. 